\title{
Ultrasound-based markers of carotid atherosclerosis correlate well with the number of classical atherosclerotic risk factors
}

\section{Ultrasonograficzne wykładniki miażdżycy tętnic szyjnych wykazuja korelacię z liczbq klasycznych czynników ryzyka miażdżycy}

\author{
Radosław Kaźmierski', Sławomir Michalak², Woiciech Kozubski \\ 'Department of Neurology and Cerebrovascular Disorders, Poznan University of Medical Sciences, L. Bierkowski MSWiA Hospital, Poznań, Poland \\ 2Department of Neurochemistry and Neuropathology, Poznan University of Medical Sciences, Neuroimmunological Unit, Polish Academy of Sciences \\ ${ }^{3}$ Department of Neurology, Poznan University of Medical Sciences, H. Święcicki Hospital, Poznań, Poland
}

Neurologia i Neurochirurgia Polska 2011; 45, 4: 317-327

\begin{abstract}
Background and purpose: Ultrasound-based indicators such as mean or maximal carotid intima-media thickness (CIMT) and cross-sectional plaque area (C-SPA) have been shown to be measurable indices of atherosclerosis. We investigated whether those indicators correlated with the number of atherosclerotic risk factors assessed in routine clinical practice.

Materials and methods: The study involved a group of 150 patients (median age, 65 years). High-resolution ultrasound was used to assess CIMT and C-SPA of their common and internal carotid arteries. The number of risk factors derived from clinical examination (e.g., hypertension, diabetes, smoking), haematological test, acute phase proteins, serum lipoproteins, homocysteine, and body mass index was assessed.

Results: Plaques occurred in 85 patients (57\% of participants). The median plaque area was $21 \mathrm{~mm}^{2}\left(10.7-46.5 \mathrm{~mm}^{2}\right)$, and the mean CIMT was $0.88 \mathrm{~mm}$ (standard deviation, $0.28 \mathrm{~mm}$ ). The study found significant associations among most of the single as well as the total number of risk factors and mean and maximal CIMT and C-SPA. The differences among the groups of patients with different numbers of risk factors were more evident in terms of the maximal and mean CIMT than in the case of C-SPA. Assessment of C-SPA could be statis-
\end{abstract}

\section{Streszczenie}

Wstęp i cel pracy: Ultrasonograficzne parametry morfologiczne tętnic szyjnych, takie jak średnia i maksymalna grubość błony środkowej i wewnętrznej ściany naczyniowej (grubość kompleksu intima-media, GKIM) oraz powierzchnia przekroju poprzecznego (PP) blaszek miażdżycowych, są uznanymi wykładnikami miażdżycy. Celem pracy było zbadanie, czy istnieje zależność pomiędzy liczbą czynników ryzyka rozwoju miażdżycy ocenianych w rutynowej praktyce klinicznej a zmianami GKIM oraz występowaniem i wielkością powierzchni PP blaszek miażdżycowych w zewnątrzczaszkowych odcinkach tętnic szyjnych.

Materiał i metody: W badaniu wzięło udział 150 pacjentów (mediana wieku: 65 lat). Powierzchnię PP blaszek miażdżycowych oraz GKIM w zewnątrzczaszkowym odcinku tętnic szyjnych wspólnych i wewnętrznych oceniono przy użyciu ultrasonografii wysokiej rozdzielczości. Liczbę czynników ryzyka miażdżycy określano na podstawie badania klinicznego (nadciśnienie tętnicze, cukrzyca, palenie tytoniu) oraz laboratoryjnych oznaczeń hematologicznych, badania białek ostrej fazy, lipoprotein, homocysteiny i wskaźnika masy ciała.

Wyniki: Blaszki miażdżycowe występowały u 85 pacjentów (57\%). Mediana powierzchni PP blaszki wynosiła $21 \mathrm{~mm}^{2}$

Correspondence address: Prof. Radosław Kaźmierski, MD, PhD, Department of Neurology and Cerebrovascular Disorders, Poznan University of Medical Sciences, L. Bierkowski MSWiA Hospital, ul. Dojazd 34, 60-631 Poznań, Poland, e-mail: rkazmierski@ump.edu.pl

Received: 27.08.2010; accepted: 15.03.2011 
tically underpowered because only $57 \%$ of the investigated subjects had plaques in their carotid arteries.

Conclusions: We found a significant correlation between the total number of atherosclerosis risk factors and carotid atherosclerosis as measured by ultrasonography. Along with an increase of the number of risk factors, a gradual increase of CIMT and C-SPA was observed.

Key words: atherosclerosis, risk factors, ultrasonography, carotid plaques, carotid arteries, intima-media thickness.

\section{Introduction}

The combined thickness of internal and medial layers (intima-media thickness - IMT) of the carotid wall and plaques of the common carotid artery (CCA), as well as the extracranial part of the internal carotid artery (ICA) walls, can be easily and reliably measured using non-invasive high-resolution B-mode ultrasonography. These ultrasound-based markers of atherosclerosis are the most useful in clinical practice, especially in neurology, cardiology, and preventive medicine [1]. Largescale epidemiological studies have demonstrated that carotid IMT (CIMT) and cross-sectional plaque area (C-SPA) are directly associated with increased risk of stroke or myocardial infarct (MI) [2-6].

The American Heart Association recommends the use of B-mode ultrasound for carotid arteries as a wellestablished noninvasive imaging modality to screen for subclinical atherosclerosis [7].

CIMT and C-SPA have also been shown to correlate with most of the well-established risk factors of atherosclerosis, as well as a number of novel ones $[3,5,6,8-10]$.

Substantially less attention has been paid to the clustering of multiple different risk factors in one patient and the possible synergistic effect clustering may have on atherosclerosis development.
(10,7-46,5 $\mathrm{mm}^{2}$ ), a średnia GKIM 0,88 mm (odchylenie standardowe: 0,28 mm). Stwierdzono zależność pomiędzy występowaniem większości pojedynczych czynników ryzyka oraz ich całkowitą liczbą a średnią i maksymalną GKIM oraz powierzchnią PP blaszek. Najsilniejsze korelacje zaobserwowano dla średniej i maksymalnej GKIM, a następnie dla powierzchni PP blaszek miażdżycowych. Korelacja pomiędzy powierzchnią PP blaszek a liczbą czynników ryzyka mogła być niedoszacowana, ponieważ tylko u $57 \%$ badanych osób stwierdzono blaszki miażdżycowe.

Wnioski: Stwierdzono istotną zależność pomiędzy liczbą czynników ryzyka a wykładnikami miażdżycy tętnic szyjnych ocenionych metodą ultrasonografii. Wraz ze zwiększaniem się liczby czynników ryzyka miażdżycy obserwowano stopniowy wzrost zarówno GKIM, jak i powierzchni PP blaszek miażdżycowych.

Słowa kluczowe: miażdżyca, czynniki ryzyka, ultrasonografia, blaszki miażdżycowe, tętnice szyjne, grubość kompleksu intima-media.

Taking the above into consideration, we investigated whether CIMT and C-SPA, measured by ultrasonography, correlated with the number of atherosclerosis risk factors assessed in routine clinical practice in an age-homogeneous population, which consisted of subjects with ages ranging from 60 to 69 years.

We also sought to determine which of the ultrasound-based measurable indexes of carotid atherosclerosis (mean CIMT, maximal CIMT or carotid C-SPA) showed the best correlation with the total number of risk factors that were assessed in routine clinical practice.

\section{Material and methods}

All 150 consecutive patients ( 70 women), with a median age of 65 years, who were enrolled with the Laboratory for Cerebrovascular Disorders (at the Department of Neurology, Poznan University of Medical Sciences), fulfilled this study's inclusion/exclusion criteria and were analysed by carotid B-mode ultrasound imaging.

The study was approved by the Medical School Ethics Committee, and each recruited participant gave his or her informed consent.

\section{Exclusion criteria}

A recent infectious disease (within the last 4 weeks), an autoimmune disorder, a brain infarction and an MI 
which occurred within the last 12 months, are all related to increased leukocyte counts, plasma fibrinogen levels and C-reactive protein (CRP) serum concentrations [11] or may have influenced changes in lipoprotein serum levels [12]. Therefore, subjects who had experienced any infectious disease within the preceding 4 weeks or had a stroke or an MI within 12 months prior to the commencement of the study were excluded.

Those who had undergone carotid surgery or angioplasty, as well as patients treated with drugs that decreased the levels of inflammatory markers, lipoproteins or homocysteine within the last year (e.g., statins [HMG-CoA inhibitors], steroids, vitamins $\mathrm{B}_{6}, \mathrm{~B}_{12}$, folic acid) were also excluded from the study.

\section{Ultrasound examinations}

All measurements were performed in accordance with the Mannheim Carotid Intima-Media Thickness Consensus (2006) (Mannheim Consensus) [1].

Measurements were obtained with high-resolution B-mode ultrasound (Sonoline Sienna, Siemens; Germany; 7.5 MHz linear probe), and each patient was examined while in the supine position by one of the authors (R.K.).

The CIMT and plaques were assessed as previously described in detail $[13,14]$.

In brief, the carotid artery was divided into three segments. The first segment included the distal $2 \mathrm{~cm}$ of the vascular wall of the CCA adjacent to the dilatation of the bifurcation. The second segment - the carotid bifurcation - is located between the carotid dilatation and the flow divider of the internal and external carotid arteries. The third segment included $1 \mathrm{~cm}$ of the proximal ICA (Fig. 1). The left and right carotid arteries were scanned in both the anteroposterior and lateral planes. IMT was measured on a longitudinal scan of the far walls of the arteries, and it was defined as the distance between the lumen-intima interface and the mediaadventitia interface (Fig. 2).

The measurements were performed at $5-\mathrm{mm}$ intervals at a distance of $2 \mathrm{~cm}$ from the CCA ( 5 measurements in each plane), in the bulb at $5-\mathrm{mm}$ intervals depending on the bulb length (2 to 4 measurements) and in the ICA at 5-mm intervals (3 measurements in each plane). In total, 20 to 24 measurements were performed on each artery. The images for CIMT measurements were taken from the end of the diastolic frame of the cineloop recording as previously described $[13,14]$, stored and later analysed off-line on the same system by the same sonographer (R.K.). All measurements were performed using the machine's electronic caliper.

The mean CIMT was calculated as the mean of all the measurements on both sides, and the maximal CIMT was calculated as the mean of the maximal measurements from all segments from both sides.

The C-SPA was assessed as described by Spence et al. $[5,6,15]$. The plane in which the measurement of each plaque was made was chosen by panning around the artery until the view showing the largest extent of that plaque was obtained. To shorten the time of each patient's ultrasound examination, the images were captured and saved for off-line analysis. Afterwards, each plaque crosssectional area was measured off-line by tracing around the perimeter with the cursor on the scanner screen (Fig. 3). The cross-sectional area of all the plaques was assessed using the scanner software. If there were two or more plaques in the same artery, the sum of all the crosssectional areas of all the plaques seen were taken as the

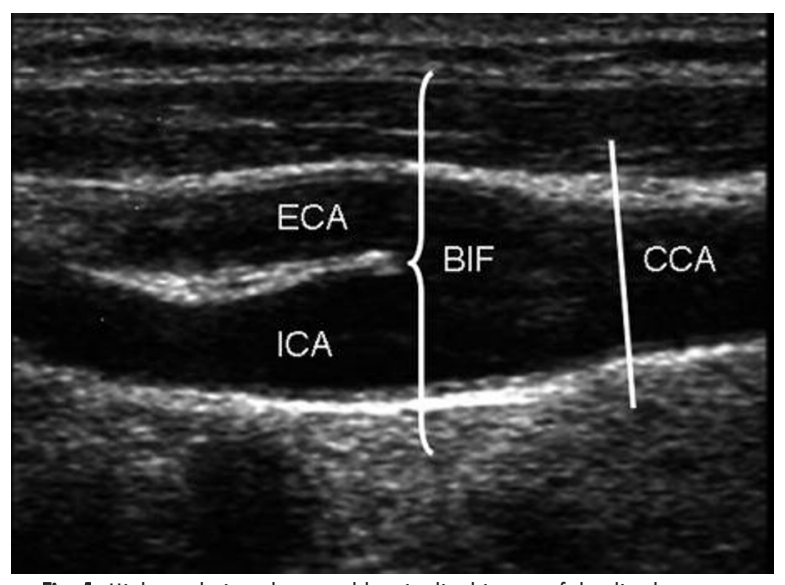

Fig. 1. High-resolution ultrasound longitudinal image of the distal common carotid artery (CCA), bifurcation (BIF), and the proximal internal carotid arteries (ICA), and external carotid arteries (ECA) as defined by study protocol

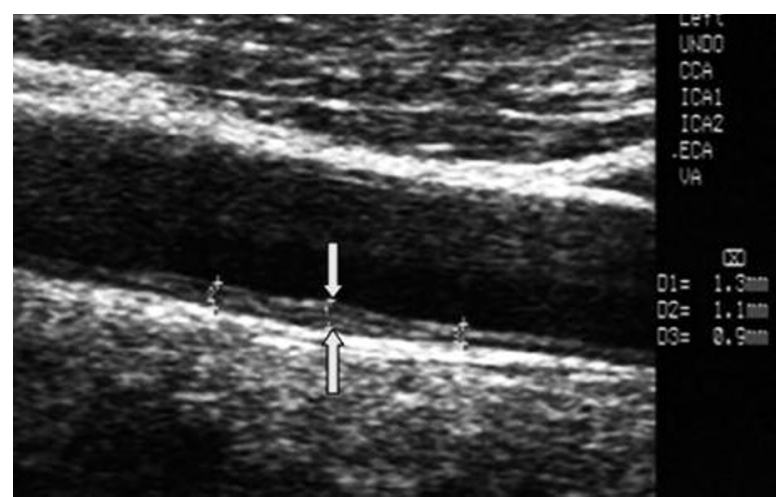

Fig. 2. The arrows indicate increased intima-media thickness on the far wall of the carotid artery 


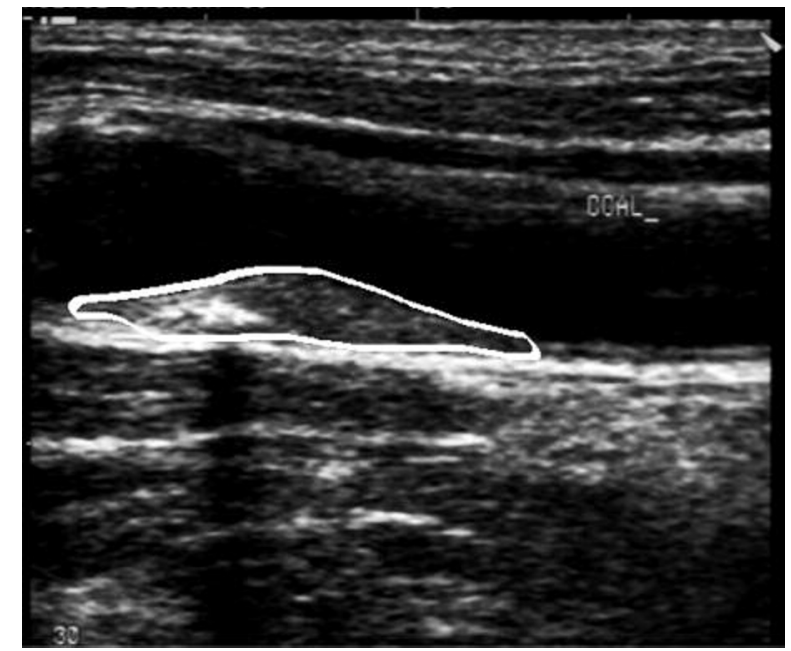

Fig. 3. Measurement of carotid plaque cross-sectional area

total C-SPA $[5,15]$. Additionally, the Duplex colour mode was used to ensure that no hypoechogenic (echolucent) plaques were missed in the examined region.

\section{Reproducibility of the measurements}

Intraobserver variability for CIMT and C-SPA (performed twice at a two-week interval for a sample of 25 subjects (50 arteries)) was expressed in terms of the repeatability coefficients, according to the BlandAltman method [16]. It showed reliable reproducibility, as described in detail elsewhere $[13,14,17]$.

\section{Clinical and laboratory examinations}

At each examination, a questionnaire requesting information on demographic background and medical history was completed.

Blood pressure was measured after 10 minutes of rest in the sitting position. Subjects were considered hypertensive if their systolic blood pressure (assessed on repeated measurements) was $\geq 140 \mathrm{~mm} \mathrm{Hg}$, if their diastolic blood pressure was $\geq 90 \mathrm{~mm} \mathrm{Hg}$ or if they were taking antihypertensive medication. Subjects were defined as diabetic if their fasting glucose level was $\geq 7.00 \mathrm{mmol} / \mathrm{L}(126 \mathrm{mg} / \mathrm{dL})$ at least twice within a 48 hour interval or if they were taking antidiabetic medication. They were classified as smokers if they smoked at least one cigarette per day, as nonsmokers if they had never smoked or as ex-smokers if they had quit smoking $>1$ year prior to examination. Body mass index (BMI) was calculated for each subject on the day of examination.
After 12 hours of fasting, blood was drawn once. Serum lipoproteins were measured using standard enzymatic methods (Synchron CX 7 analyzer; Beckman, USA) and low-density lipoprotein cholesterol (LDL-C) was calculated by the Friedewald formula [18].

Serum glucose was assessed using an EBIOBASIC glucose analyser (Eppendorf, Germany). The blood morphology was assessed with an automated method (Sysmex K4500, USA), and the fibrinogen plasma concentration was assessed by nephelometry (Nephelometer ACL 100, USA). CRP serum concentrations were measured with a high-sensitivity immunoassay, and analyses were performed with the Behring Nephelometer BN II (Dade Behring, Germany). The plasma concentrations of homocysteine were measured using high-performance liquid chromatography (Gyncotek, Germany) with an electrochemical detector (CoulArray 5600, ESA; USA) as described elsewhere [19].

The atherosclerotic risk factors were predefined according to the guidelines of the American Heart Association: Guidelines for Primary Prevention of Cardiovascular Disease and Stroke, Third Report of the National Cholesterol Education Program, and European guidelines on cardiovascular disease prevention in clinical practice [20-22] and our university hospital laboratory's reference values. To investigate the relationship between the number of atherosclerotic risk factors and carotid CIMT or C-SPA, we classified each patient according to the presence of single or multiple risk factors. Patients were considered to be at risk when one or more of the following criteria were satisfied: total cholesterol (T-Chol) > $200 \mathrm{mg} / \mathrm{dL}$, LDL-C $>135 \mathrm{mg} / \mathrm{dL}$, high density cholesterol (HDL-C) $<40 \mathrm{mg} / \mathrm{dL}$, T-Chol/HDL ratio $>5$, triglycerides $>200 \mathrm{mg} / \mathrm{dL}$, homocysteine concentration $>15 \mu \mathrm{mol} / \mathrm{L}$, fibrinogen level $>400 \mathrm{mg} / \mathrm{dL}, \mathrm{CRP}$ concentration $>3.5 \mathrm{mg} / \mathrm{L}$, white blood cells $>109 / \mathrm{L}$, BMI $>26 \mathrm{~kg} / \mathrm{m}^{2}$ as well as hypertension, diabetes, smoking habits, and history of ischaemic heart disease (IHD), MI or ischaemic stroke.

A separate analysis was performed for the dataset after excluding nonmodifiable risk factors such as MI, IHD or ischaemic stroke in history and estimated lipid parameters (such as LDL-C calculated by the Friedewald formula and T-Chol/HDL ratio).

\section{Statistical analysis}

Data are given as the mean \pm standard deviation (SD), and for non-normal measurements (according to 
the Shapiro-Wilk test), data are given as the geometric mean ( $\pm 1 \mathrm{SD})$. The data that showed an asymmetric distribution and met the remaining criteria for a normal distribution were log or cubic transformed $\left(\mathrm{p}_{\mathrm{tr}}\right)$ and analysed with the relevant parametric tests.

The associations between the selected variables were analysed by Pearson linear correlation, multiple regression and partial correlation analysis (on transformed data), as well as non-parametric Spearman rank or gamma correlation for non-normally distributed data or for pairs including discrete variables. Clinical parameters were ranked based on the presence or absence of a given characteristic.

The Kruskal-Wallis nonparametric ANOVA or the Tukey-Kramer test was employed to assess the significance of differences of ultrasound-based markers between the groups categorized according to the number of risk factors. Statistical analyses were performed using either Statistica for Windows (version 5.5) or MedCalc (version 10.3.1.0).

\section{Results}

The baseline clinical characteristics of patients studied (based on presence or absence of a given risk factor) are shown in Table 1, and the laboratory results are shown in Table 2.

\section{Ultrasonography of carotid arteries}

Across all examined arteries, the mean CIMT was $0.88 \mathrm{~mm}$ (SD 0.28; median, $0.83 \mathrm{~mm}$, interquartile range: $0.67-1.07 \mathrm{~mm}$ ), and the median of the maximal CIMT was $0.9 \mathrm{~mm}$ (interquartile range: $0.8-1.2 \mathrm{~mm}$ ). Plaques occurred in 85 patients $(56.7 \%$ of study participants). The median of the total C-SPA was $21 \mathrm{~mm}^{2}$ (interquartile range: $10.7-46.5 \mathrm{~mm}^{2}$ ).

Using the $\chi^{2}$ test, a significant correlation $(p=$ 0.0005 ) was found between plaque occurrence and the number of risk factors. In the first group (1 to 3 risk factors), there were 5 subjects with plaques (29.4\%) out of 17 patients. In the second group (4 to 6 risk factors), there were 31 subjects with plaques $(50 \%)$ out of 62 patients. In the third group ( 7 to 9 risk factors), there were 28 subjects with plaques (58.3\%) out of 48 patients, and in the fourth group (over 9 risk factors) there were 21 subjects with plaques (91.3\%) out of 23 patients.

Plaque occurrence was also significantly different $(p<0.01)$ between groups with and without a history of stroke, IHD or MI. Of the 68 symptomatic subjects,
52 subjects $(76.5 \%)$ had plaques in their carotid arteries, but among the 82 asymptomatic subjects, there were only $33(40.2 \%)$ with plaques.

In the symptomatic group 12 patients had a history of IHD or MI, but no stroke, and 7 of these patients (58.3\%) had plaques.

Univariate analysis revealed that all the dichotomized conventional risk factors of atherosclerosis demonstrated strong correlations with all ultrasound-based parameters. Also some of the laboratory parameters correlated well with CIMT and plaque area (Tables 3 and 4).

There were significant correlations between the number of risk factors and the mean and maximal CIMT as well as plaque area (Figs. 4A, 5A, 6A and 4B, 5B, 6B).

Table 1. Clinical characteristics of study group $(n=150)$

\begin{tabular}{|lcc|}
\hline Risk factor & $\begin{array}{c}\text { Number } \\
\text { of subjects }\end{array}$ & Proportion \\
\hline Hypertension & 68 & $45.3 \%$ \\
\hline Diabetes (type II, treated) & 19 & $12.7 \%$ \\
\hline Cigarette smoking (active) & 51 & $34.0 \%$ \\
\hline Past smokers & 28 & $18.7 \%$ \\
\hline $\begin{array}{l}\text { Ischaemic heart disease/ } \\
\text { Myocardial infarct }\end{array}$ & 36 & $24.0 \%$ \\
\hline History of ischaemic stroke & 56 & $37.3 \%$ \\
\hline $\begin{array}{l}\text { Variables are shown as dichotomies ranked based on the presence or absence of a given charac- } \\
\text { teristic }\end{array}$
\end{tabular}

Table 2. Laboratory data in the study group $(n=150)$

\begin{tabular}{|lc|}
\hline Variable & $\begin{array}{c}\text { Mean (SD) } \\
\text { or *median } \\
\text { (interquartile range) }\end{array}$ \\
\hline White blood cell count $\left[\times 10^{9} / \mathrm{L}\right]$ & $6.4(2.20)$ \\
\hline Glucose $[\mathrm{mg} / \mathrm{dL}]$ & $88.7(6.9)$ \\
\hline \begin{tabular}{l} 
Plasma lipids \\
\hline Total cholesterol $[\mathrm{mg} / \mathrm{dL}]$
\end{tabular} & $235(45)$ \\
\hline HDL cholesterol $[\mathrm{mg} / \mathrm{dL}]$ & $49(12)$ \\
\hline LDL cholesterol $[\mathrm{mg} / \mathrm{dL}]$ & $119(88-159)^{*}$ \\
\hline Triacylglycerides $[\mathrm{mg} / \mathrm{dL}]$ & $4.9(4.1-4.9)^{*}$ \\
\hline Total cholesterol/HDL cholesterol ratio & $16.1(12.7-21.1)^{*}$ \\
\hline Homocysteine $[\mu \mathrm{mol} / \mathrm{L}]$ & $412(91)$ \\
\hline Fibrinogen $[\mathrm{mg} / \mathrm{dL}]$ & $2.3(0.85-5.79)^{*}$ \\
\hline CRP $[$ mg/L] & $26.0(23.5-27.7)^{*}$ \\
\hline Body mass index $\left[\mathrm{kg} / \mathrm{m}^{2}\right]$ & \\
\hline
\end{tabular}

$S D$ - standard deviation 
Table 3. Associations between the occurrence of selected conventional biochemical risk factors, BMI and maximal carotid intima-media thickness (CIMT), mean CIMT, and carotid cross-sectional plaque area

\begin{tabular}{|c|c|c|c|c|c|c|}
\hline \multirow[t]{2}{*}{ Variable } & \multicolumn{2}{|c|}{ Mean CIMT } & \multicolumn{2}{|c|}{ Maximal CIMT } & \multicolumn{2}{|c|}{$\begin{array}{c}\text { Carotid plaque } \\
\text { cross-sectional area }\end{array}$} \\
\hline & $\begin{array}{l}R \text {-value } \\
\text { or } r \text {-value }\end{array}$ & $p$-value & $\begin{array}{c}R \text {-value } \\
\text { or } r \text {-value* }\end{array}$ & $p$-value & $\begin{array}{c}R \text {-value } \\
\text { or } r \text {-value** }\end{array}$ & p-value \\
\hline White blood cell count $(n=14[9 \%])$ & 0.45 & 0.0001 & 0.36 & 0.0001 & 0.40 & 0.0001 \\
\hline \multicolumn{7}{|l|}{ Plasma lipids } \\
\hline Total cholesterol $(n=112[75 \%])$ & 0.10 & 0.732 & 0.06 & 0.875 & 0.12 & 0.234 \\
\hline HDL cholesterol $(n=45[30 \%])$ & -0.36 & 0.0001 & -0.27 & 0.004 & -0.28 & 0.005 \\
\hline LDL cholesterol $(n=114[76 \%])$ & 0.17 & 0.351 & 0.13 & 0.453 & 0.15 & 0.145 \\
\hline Triacylglycerides $(n=36[24 \%])^{*}$ & 0.32 & 0.001 & 0.21 & 0.021 & 0.15 & 0.119 \\
\hline $\begin{array}{l}\text { Total cholesterol/HDL } \\
\text { cholesterol ratio }(n=46[31 \%])^{*}\end{array}$ & 0.33 & $<0.0001$ & 0.24 & 0.010 & 0.25 & $<0.0001$ \\
\hline Homocysteine $(n=74[49 \%])^{*}$ & 0.19 & 0.036 & 0.15 & 0.108 & 0.16 & 0.076 \\
\hline Fibrinogen $(n=82[55 \%])$ & 0.31 & $<0.0001$ & 0.24 & 0.011 & 0.23 & 0.008 \\
\hline $\mathrm{CRP}(n=58[39 \%]) *$ & 0.43 & 0.0001 & 0.40 & 0.0001 & 0.41 & 0.0001 \\
\hline Body mass index $(n=72[48 \%])^{*}$ & 0.18 & 0.048 & 0.15 & 0.170 & 0.20 & 0.022 \\
\hline
\end{tabular}

*Associations of variables showing departures from normal distribution are presented as Spearman's rank correlation coefficients ( $r$ ).

Associations of the remaining variables are estimated by Pearson's correlation coefficient $(R)$.

The number (n) and percentage (\%) of subjects who fulfilled the study criteria for a risk factor are provided in parentheses.

Significant correlations $(p<0.05)$ are shown in bold.

Table 4. Associations between occurrence of selected conventional clinical risk factors and mean and maximal CIMT as well as carotid plaque cross-sectional area

\begin{tabular}{|lcccccc|}
\hline Variable* & \multicolumn{2}{c}{$\begin{array}{c}\text { Mean carotid } \\
\text { intima-media thickness }\end{array}$} & $\begin{array}{c}\text { Maximal carotid } \\
\text { intima-media thickness }\end{array}$ & \multicolumn{2}{c|}{$\begin{array}{c}\text { Carotid plaque } \\
\text { cross-sectional area }\end{array}$} \\
\cline { 2 - 7 } & $\boldsymbol{R}$ & $\mathbf{p}$-value & $\boldsymbol{R}$ & $\mathbf{p}$-value & $\boldsymbol{R}$ & $\mathbf{p}$-value \\
\hline Hypertension (treated) & 0.46 & $<0.0001$ & 0.44 & $<0.0001$ & 0.44 & $<0.0001$ \\
\hline Diabetes (treated) & 0.53 & 0.0002 & 0.45 & 0.0004 & 0.41 & 0.012 \\
\hline Smoking (active) & 0.32 & $<0.0001$ & 0.30 & $<0.0001$ & 0.34 & $<0.0001$ \\
\hline $\begin{array}{l}\text { Ischaemic heart disease } \\
\text { and myocardial infarct }\end{array}$ & 0.52 & $<0.0001$ & 0.49 & $<0.0001$ & 0.50 & $<0.0001$ \\
\hline Ischaemic stroke & 0.72 & $<0.0001$ & 0.65 & $<0.0001$ & 0.51 & $<0.0001$ \\
\hline
\end{tabular}

*Variables are shown as dichotomies ranked based on the presence or absence of a given characteristic. Associations $(R)$ represent gamma correlation coefficients.

Significant correlations $(p<0.05)$ are shown in bold.

A positive correlation was found between mean CIMT values and 13 out of the 15 parameters, and maximal CIMT correlated significantly with 10 parameters. Plaque area correlated significantly with 11 out of 15 parameters.

We observed a significant increase of mean and maximal CIMT and C-SPA values across all groups of patients categorized according to the number of risk factors (see Figures 4A, 5A and 6A for details).

Similar correlations were also found when nonmodifiable risk factors such as stroke, IHD and MI in his- tory as well as calculated lipid parameters (LDL-C level and T-Chol./HDL ratio) were excluded from the dataset (see Figures 4B, 5B and 6B for details).

Chi-square and Cochran-Armitage test for trend showed significance in all ultrasound parameters $(p=$ 0.001).

Additionally, values of C-SPA were significantly different between the group with $\geq 10$ risk factors and all other groups. There were also significant differences in terms of plaque area between the third group (with 7 to 9 risk factors) and the first and fourth groups (Fig. 6A). 


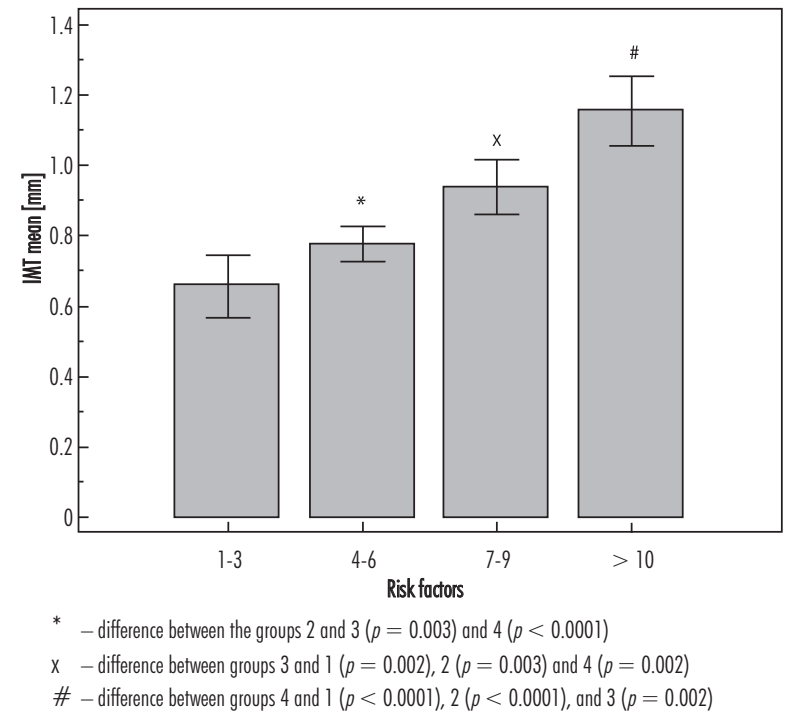

Fig. 4A. Correlations of mean CIMT of all three segments of carotid arteries and groups of patients with different numbers of risk factors

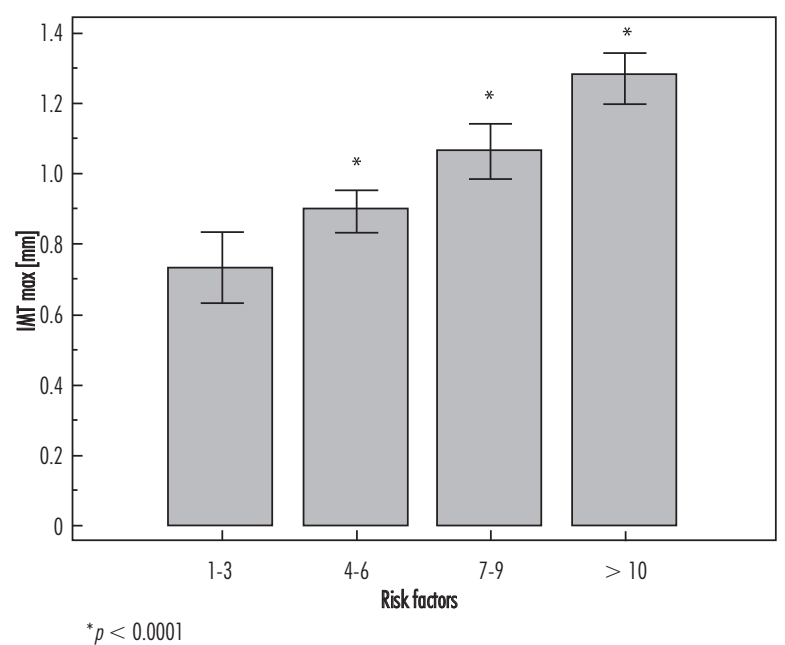

Fig. 5A. Correlations between maximal CIMT of all three segments of carotid arteries and groups of patients with different numbers of risk factors

There were also significant differences between group 4 or 3 and group 1 or 2 when MI, IHD and stroke as well as calculated lipid parameters in history were excluded (Fig. 6B).

\section{Discussion}

In terms of mean and maximal IMT as well as $\mathrm{C}$-SPA, the present pilot study identified significant

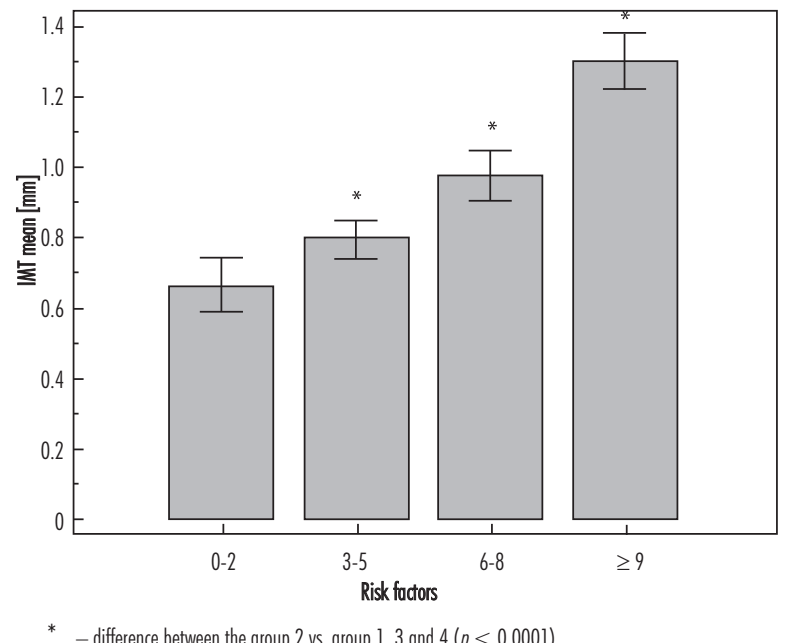

Fig. 4B. Correlations of mean CIMT of all three segments of carotid arteries and groups of patients with different numbers of risk factors (with exclusion of MI, IHD, stroke and calculated lipid parameters)

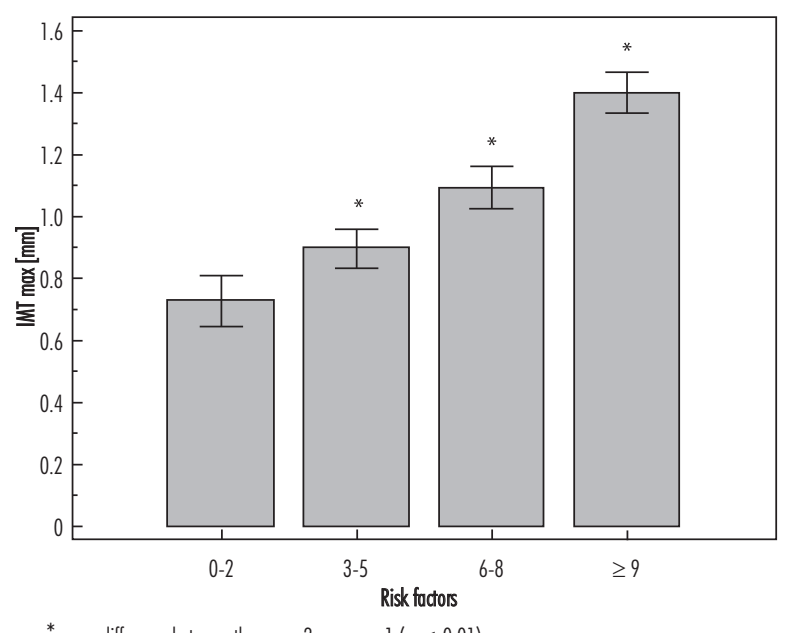

Fig. 5B. Correlations between maximal CIMT of all three segments of carotid arteries and groups of patients with different numbers of risk factors (with exclusion of MI, IHD, stroke and calculated lipid parameters)

associations between most of the well-established single cardiovascular risk factors and the development of carotid atherosclerosis. The differences among groups of patients with different numbers of risk factors were more evident in terms of maximal and mean CIMT than in the case of plaque area.

One possible explanation of this weaker correlation of C-SPA is the smaller cohort of patients with plaques. However, simultaneously with the increasing number of 


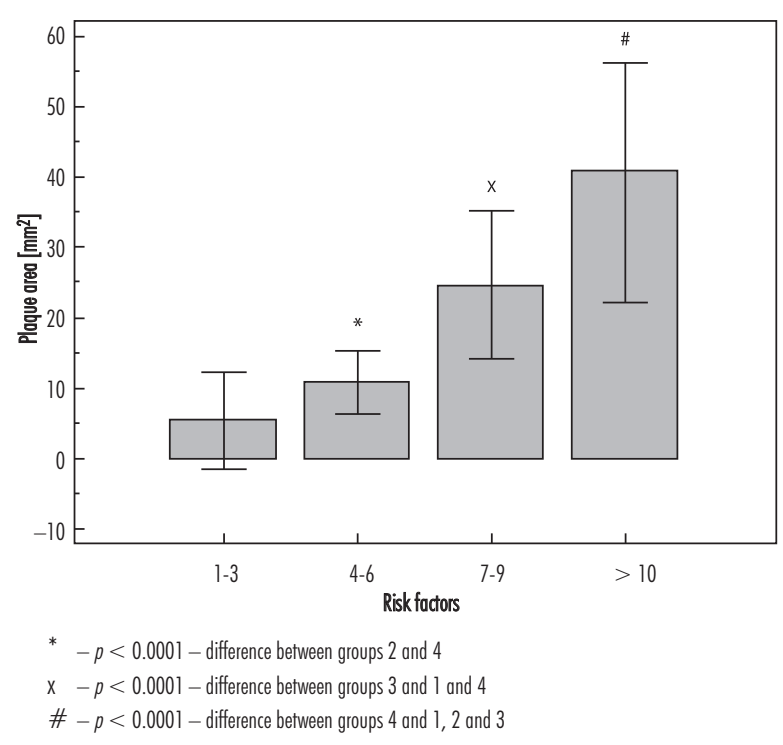

Fig. 6A. Correlations between total plaque areas from all three segments of the carotid arteries and groups of patients with different numbers of risk factors

risk factors, the proportion of subjects with plaques and plaque area increased as well (from $21.4 \%$ in the subgroup with the lowest number of risk factors to $91.3 \%$ in the group with the highest number of risk factors).

In this study, we also included the following clinical events as risk factors: stroke, MI and IHD. Naturally, stroke or MI per se did not cause an increase in CIMT or plaque volume, but it has been shown that patients with stroke, IHD or MI had a larger number of cumulative risk factors than healthy subjects within the same age range $[3,4,9,14]$. Similar methodology was used in a recent large-scale population study [23].

Therefore, the inclusion of these factors is viable because the artery wall morphology reflects the effect of all risk factors on an artery wall, even those that were not examined in this study or are still unknown (e.g., genetic factors). In our previous study, we found that CIMT and C-SPA showed better correlations with stroke occurrence than the currently recognized biochemical and clinical risk factors [14]. However, similar correlations between carotid artery morphology and number of risk factors were found when the nonmodifiable risk factors (stroke, IHD and MI in history) as well as calculated lipid parameters (LDL-C level and T-Chol/HDL ratio) were excluded from the dataset (Figs. 4B, 5B, 6B).

We excluded patients taking statins for two reasons: (1) statins act via effects on lipoproteins and inflamma-

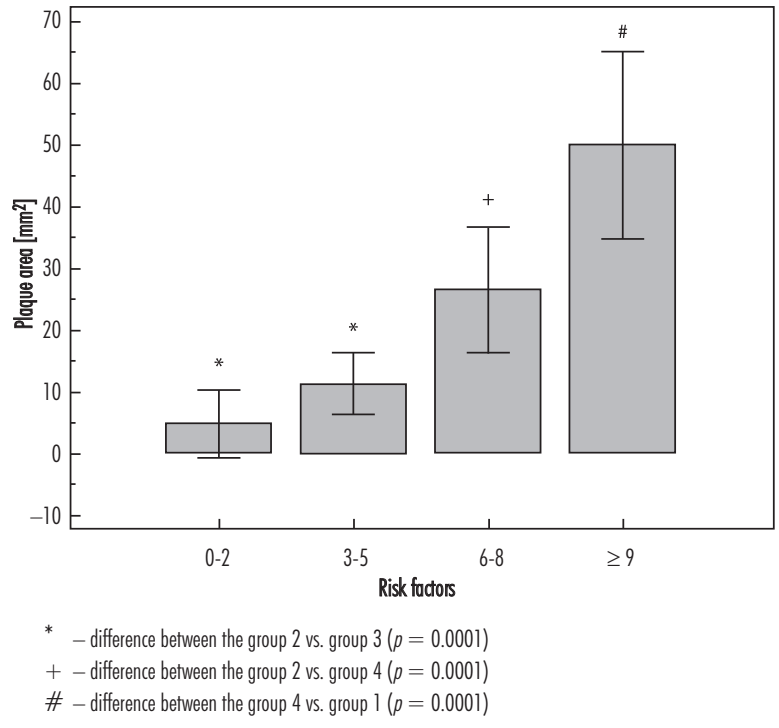

Fig. 6B. Correlations between total plaque areas from all three segments of the carotid arteries and groups of patients with different numbers of risk factors (with exclusion of MI, IHD, stroke and calculated lipid parameters)

tory markers (CRP, fibrinogen, increased number of white blood cells), which are well-known risk factors [24], and (2) aggressive, longer treatment with statins (especially atorvastatin) can cause CIMT regression [24,25]. Patients taking antihypertensive drugs were not excluded because it has been proven in a large meta-analysis by Wang et al. as well as in other studies that antihypertensive therapy does not influence baseline artery morphology, but antihypertensive therapy usually reduces the yearly increase in CIMT [26-28]. Additionally, a recent study by Zanchetti et al. has shown that CIMT and plaques are an important added risk to cardiovascular outcomes in a treated hypertensive population, independent of blood pressure and other traditional risk factors [29].

Currently, there is no definitive answer as to which value - mean CIMT, maximal CIMT or C-SPA should be measured [1]. However, the answer to the question of which parameter, mean maximum CIMT or the mean of all measurements, is more useful in clinical practice, especially in preventive medicine, remains controversial [1].

\section{Carotid intima-media thickness measurements}

Some authors suggest that maximal CIMT measurements should be primarily assessed with studies focused on the predictive usefulness of carotid wall ultrasound measurements [30-33]. 
For example, Kabłak-Ziembicka et al. demonstrated, in a prospective study, that the mean of maximal CIMT measurements (of both carotid arteries) was an independent predictor of significant multi-level atherosclerosis (in coronary, renal angiography and supra-aortic, iliac/femoral arteries). Such a measure has high sensitivity and specificity for indicating more advanced territorial atherosclerotic involvement, and it is also an important predictor of death due to a cardiovascular cause [32]. In another study, it was demonstrated that maximal CIMT is a strong, independent predictor of death and serious cardiovascular events in hypertensive patients with coronary artery disease [33].

Maximal CIMT showed a higher magnitude of association with cardiovascular risk factors than did mean CIMT. It has been suggested that maximal CIMT is more precise for estimating an individual level of atherosclerosis and occurrence of risk factors $[30,31]$. In the Muscatine Study conducted in a younger population (age range: 33 to 42 years), the mean maximal CIMT provided a better correlation with current risk factors than did the use of only mean CIMT [34].

In clinical settings, however, there are several compelling arguments in favour of mean CIMT measurements for all three segments of the carotid artery. A local increase of CIMT, especially in bifurcation, does not reflect atherosclerosis only; it could also be a monographic sign of intimal hyperplasia or intimal fibrocellular hypertrophy, which are morphological forms of reactive intimal modelling that are different from atherosclerosis [35].

According to Bots et al. [36], a mean CIMT can be assessed in a more reproducible manner than a maximum CIMT. However, many studies showed similar reproducibility of maximal CIMT. The maximal values of CIMT often occurred in ICA sites where the artery wall could be less clearly visualized $[10,37,38]$.

This is important from a methodological point of view, because it has been demonstrated that statistical analysis of incomplete data can lead to less precise IMT assessment and increased bias in the assessment of progression rates of IMT over time in prospective studies [39]. The mean CIMT has been shown to be a reliable predictor of future cardiovascular events with similar statistical power as maximal CIMT $[3,10,40]$.

Therefore, a mean rather than a maximal CIMT measurement provides more complete data sets, especially when measurements from the ICA have more missing values.
The mean CIMT values averaged across all three segments (as was done in our study) are less susceptible to outliers, whereas the maximal CIMT may only reflect focal thickening [1].

Our study has also demonstrated similar correlations between mean and maximal CIMT and several atherosclerosis risk factors. Therefore, we can state that both methods of measurement can be reliably used in epidemiological studies as well as in the assessment of ultrasonographic signs of atherosclerosis for a patient.

\section{Assessment of plaque cross-sectional area}

Correlations between C-SPA and different single risk factors were demonstrated previously $[5,6]$ but less attention was paid to the correlation of C-SPA with the total number of risk factors. In this study, we observed a significant correlation between the number of risk factors and plaque area.

In our study, C-SPA did not show better associations with risk factors compared to either method of CIMT measurement. One possible explanation is that only $57 \%$ of study participants have plaques in their carotid arteries, so the plaque analysis is likely underestimated in this study.

Both plaques and CIMT were the end points in studies assessing the effects of new therapies for atherosclerosis $[26,37]$. In such studies, plaque area was considered to be more useful because plaque progress in carotid arteries is 2.4 times faster than CIMT, so plaque area is much more sensitive to the effects of therapy than a measurement of the CIMT alone $[5,6,15]$.

One should recall, however, that, as opposed to CIMT, which could be measured in all individuals, plaques showed a strong positive relationship with age. Therefore, in younger age groups the usefulness of plaque measurements is substantially limited [41,42]. That aspect is seemingly important in planning a prospective epidemiological study.

\section{Study limitations}

In our study, we tried to include the maximal number of atherosclerosis risk factors, although one should remember that currently extensive research is being done to investigate the unexplained progression of atherosclerosis, so novel risk factors are continually being discovered. The most important novel risk factors that relate to hypertension, lipoprotein metabolism, homocysteine and its derivatives, and resistance to chronic 
infection seem to be genetic $[6,10]$. These factors were not included in our study, but the clinical significance of many of the novel factors is still the subject of investigation, as are the factors that are substantially more difficult to assess in clinical practice. Therefore, we concentrated on factors that are possible to assess in most large laboratories.

In the future, together with the widespread advent of novel ultrasound technologies, measuring threedimensional plaque volume will probably add significance and sensitivity to CIMT measurements; in particular, it could be an advantage in studies of new atherosclerosis therapies.

\section{Conclusions}

1. In a population with ages ranging from 60 to 69 years, we found a significant correlation between the number of classical atherosclerosis risk factors and carotid atherosclerosis as measured by ultrasonography. Along with an increase of the number of risk factors, a gradual increase of CIMT as well as C-SPA was observed.

2. The most significant differences among the groups of subjects with different numbers of risk factors were found for maximal CIMT and then for mean CIMT and C-SPA. On the other hand, the mean CIMT correlated with the largest number of risk factors, followed by C-SPA and maximal CIMT.

3. Because only about half of the investigated subjects had plaques in their carotid arteries, the statistical power of plaque areas could be underestimated.

\section{Acknowledgments}

The authors would like to thank Jolanta Dorszewska, $\mathrm{PhD}$, from the Laboratory of Neurobiology at Poznan University of Medical Sciences for assessing the patients' homocysteine levels.

\section{Disclosure}

The authors report no conflict of interest.

\section{References}

1. Touboul P.-J., Hennerici M.G., Meairs S., et al. Mannheim carotid intima-media thickness consensus (2004-2006). Cerebrovasc Dis 2007; 23: 75-80.
2. Bots M.L., Hoes A.W., Koudstaal P.J., et al. Common carotid intima-media thickness and risk of stroke and myocardial infarction. Circulation 1997; 96: 1432-1437.

3. O'Leary D.H., Polak J.F., Kronmal R.A., et al. Carotid- artery intima and media thickness as a risk factor for myocardial infarction and stroke in older adults. $N$ Engl J Med 1999; 340: 14-22.

4. Touboul P.-J., Elbaz A., Koller C., et al. Common carotid artery intima-media thickness and brain infarction. Circulation 2000; 102: 313-318.

5. Spence J.D., Eliasziw M., DiCicco M., et al. Carotid plaque area: a tool for targeting and evaluating vascular preventive therapy. Stroke 2002; 33: 2916-2922.

6. Spence J.D. Technology Insight: ultrasound measurement of carotid plaque - patent management, genetic research, and therapy evaluation. Nat Clin Pract Neurology 2006; 2: 611- 619.

7. Smith S.C., Jr., Greenland P., Grundy S.M. AHA Conference Proceedings. Prevention conference V: Beyond secondary prevention: Identifying the high-risk patient for primary prevention: executive summary. American Heart Association. Circulation 2000; 101: 111-116.

8. Baldassarre D., Amato M., Bondioli A., et al. Carotid artery intima-media thickness measured by ultrasonography in normal clinical practice correlates well with atherosclerosis risk factors. Stroke 2000; 31: 2426-2430.

9. Willeit J., Kiechl S., Oberhollenzer F., et al. Distinct risk profiles of early and advanced atherosclerosis: prospective results from the Bruneck Study. Arterioscler Thromb Vasc Biol 2000; 20: 529-537.

10. Kaźmierski R., Podsiadły E., Tylewska-Wierzbanowska S., et al. Związek pomiędzy zaawansowaniem miażdżycy tętnic szyjnych a wykładnikami zapalenia i zakażenia bakteriami Chlamydia pneumoniae. Neurol Neurochir Pol 2005; 39: 277-286.

11. Beamer N.B., Coull B.M., Clark W.M., et al. Persistent inflammatory response in stroke survivors. Neurology 1998; 50 : 1722-1728.

12. Butterworth R.J., Marshall W.J., Bath P.M.W. Changes in serum lipid measurement following acute ischemic stroke. Cerebrovasc Dis 1997; 7: 10-13.

13. Kaźmierski R., Watała C., Podsiadły E., et al. Association of atherosclerotic risk factors with carotid adventitial thickness assessed by ultrasonography. J Clin Ultrasound 2009; 37: 333-341.

14. Kaźmierski R., Watała C., Podsiadły E., et al. Carotid intimamedia thickness better differentiates between groups of stroke patients and persons without cerebrovascular disease than other conventional and novel risk factors. Folia Morphol 2004; 63: 253-260.

15. Barnett H.J.M., Spence J.D., Manuck S.B., et al. Psychological stress and progression of carotid atherosclerosis. J Hypertens 1997; 15: 49-55.

16. Bland J.M., Altman D.G. Statistical methods for assessing agreement between two methods of clinical measurements. Lancet 1986; 1: 307-310.

17. Kaźmierski R., Niezgoda A., Guzik P., et al. An evaluation of the reproducibility of the measurement of the intima-media thickness of carotid arteries. Folia Morphol 2003; 62, 1: 25-31.

18. Friedewald W., Levy R.I., Fredrickson D.S., Estimation of the concentration of low-density lipoprotein cholesterol in plasma, 
without use of the preparative ultracentrifuge. Clin Chem 1972; 18: 499-502.

19. Accinni R., Bartesaghi S., De Leo G., et al. Screening of homocysteine from newborn blood spots by high-performance liquid chromatography with coulometric array detection. J Chromatogr A 2000; 869: 183-189.

20. Third Report of the National Cholesterol Education Program (NCEP) Expert Panel on Detection, Evaluation, and Treatment of High Blood Cholesterol in Adults (Adult Treatment Panel III) final report. Circulation 2002; 106: 3143-3421.

21. De Backer G., Ambrosioni K., Borch-Johnsen C., et al. European guidelines on cardiovascular disease prevention in clinical practice. Eur Heart J 2003; 24: 1601-1610.

22. Pearson T.A., Blair S.N., Daniels S.R., et al. AHA guidelines for primary prevention of cardiovascular disease and stroke: 2002: update. Circulation 2002; 106: 388-391.

23. Touboul P.-J., Vicaut E., Labreuche J., et al. Common carotid artery intima-media thickness: The Cardiovascular Risk Factor Multiple Evaluation in Latin America (CARMELA) Study results. Cerebrovasc Dis 2011; 31: 43-50.

24. Taylor A.J., Kent S.M., Flaherty P.J., et al. ARBITER: Arterial biology for the investigation of the treatment effects of reducing cholesterol: a randomized trial comparing the effects of atorvastatin and provastatin on carotid intima-media thickness. Circulation 2002; 106: 2055-2060.

25. Smilde T.J., van Vissen S., Wollersheim H., et al. Effect of aggressive versus conventional lipid lowering on atherosclerosis progression in familial hypercholesterolemia (ASAP): a prospective, randomized, double-blind trial. Lancet 2001; 357 : 577-581.

26. Wang J.G., Staessen J.A., Li Y., et al. Carotid intima-media thickness and antihypertensive treatment. a meta-analysis of randomized controlled trials. Stroke 2006; 37: 1933-1940.

27. Wilklund O., Hulthe J., Wikstrand J. Effect of controlled release/extended release metoprolol on carotid intima-media thickness in patients with hypercholesterolemia: a 3-year randomized study. Stroke 2002, 33, 572-577.

28. Zanchetti A., Bond G., Hennig M., et al. on behalf of the ELSA investigators. Calcium antagonist lacidipine slows down progression of asymptomatic carotid atherosclerosis: principal results of the European Lacidipine Study on Atherosclerosis (ELSA), a randomised, duble-blind, long-term trial. Circulation 2002; 106: 2422-2427.

29. Zanchetti A., Hennig M., Hollweck R., et al. Baseline values but not treatment-induced changes in carotid intima-media thickness predict incident cardiovascular events in treated hypertensive patients: findings in the European Lacidipine Study on Atherosclerosis (ELSA). Circulation 2009; 120: 1084-1090.

30. Iglesias del Sol A., Bots M.L., Grobbee D.E., et al. Carotid intima-media thickness at different sites: relation to incident myocardial infarction. Eur Heart J 2002; 23: 934-940.

31. De Michele M., Panico S., Iannuzzi A., et al. Association of obesity and central fat distribution with carotid artery wall thickening in middle-aged women. Stroke 2002; 33: 2923-2928.

32. Kabłak-Ziembicka A., Przewłocki T., Tracz W., et al. Diagnostic value of carotid intima-media thickness in indicating multi-level atherosclerosis. Atherosclerosis 2007; 193: 395-400.
33. Zielinski T., Dzielinska Z., Januszewicz A., et al. Carotid intimamedia thickness as a marker of cardiovascular risk in hypertensive patients with coronary artery disease. Am J Hypertens 2007; 20 : 1058-1064.

34. Davis P.H., Dawson J.D., Riley W.A., et al. Carotid intimalmedial thickness is related to cardiovascular risk factors measured from childhood through middle age: the Muscatine Study. Circulation 2001; 104: 2815-2819.

35. Glagov S., Bassiouny H.S., Giddens D.P., et al. Intimal thickening: morphogenesis, functional significance and detection. $J$ Vasc Invest 1995; 1: 2-14.

36. Bots M.L., Evans G.W., Ward R.A., et al. Carotid intima-media thickness measurements in interventions studies. Progression rates, and sample size considerations: a point of view. Stroke 2003; 34: 2985-2994.

37. Tang R., Henning M., Thomasson B., et al. Baseline reproducibility of B-mode ultrasonic measurement of carotid artery intima-medai thickness: the European Lacidipine Study on Atherosclerosis (ELSA). J Hypertens 2000; 18: 197-201.

38. O'Leary D.H., Polak J.F. Intima-media thickness: a tool for atherosclerosis imaging and event prediction. Am J Cardiol 2002; 90 (suppl): 18L-21L.

39. Espeland M.A., Byington R.P., Hire D., et al. Analysis strategies for serial multivariate ultrasonographic data that are incomplete. Stat Med 1992; 11: 1041-1056.

40. Mack W.J., Selzer R.H., Hodis H.N., et al. One-year reduction and longitudinal analysis of carotid intima-media thickness associated with colestipol/niacin therapy. Stroke 1993; 24: 17791783 .

41. del Sol I.A., Moons K.G., Hollander M., et al. Is carotid intimamedia thickness useful in cardiovascular disease risk assessment? The Rotterdam Study. Stroke 2001; 32: 1532-1538.

42. Hollander M., Hak A.E., Koudstaal P.J., et al. Comparison between measures of atherosclerosis and risk of stroke. The Rotterdam Study. Stroke 2003; 34: 2367-2373. 